\title{
TEMPORAL DIFFERENCES BETWEEN GENDERS IN THE REALISATION OF SPECIFIC COMBAT TECHNIQUES RELATIVE TO SPATIAL ABILITY
}

\author{
Milan Gužvica ${ }^{1}$, Darko Paspalj, Žana Vrućinić, Lazar Vulin \\ University of Banja Luka, Faculty of Security Sciences \\ The Republic of Srpska
}

\begin{abstract}
In this paper, the time of performing 15 motor tests that consisted of different modalities of punches and kicks was measured on a sample of 44 subjects ( 24 men and 20 women), as well as the speed of performing cognitive test $\mathrm{S} 1$, from a battery of KOG3 tests. The results were obtained using appropriate statistical procedures, and they indicate that women in most cases, from both items, achieved better results compared to men when it comes to a simple motor reaction, while men achieved better results with a complex motor reaction. The obtained concurrence of motor tests with test $\mathrm{S} 1$ for men ranges from a complete absence of concurrence for five techniques derived from the left guard to high concurrence for three techniques derived from the right guard. When it comes to women, the absence of any concurrence was registered in two techniques from one and the other guard, and high concurrence for five techniques from the right guard. It is believed that the obtained results can be useful for further teaching process in Special Physical Education.
\end{abstract}

Keywords: punches, kicks, police students, motor reaction, spatial ability.

\section{INTRODUCTION}

The speed of the motor reaction, that is, the duration of mental processes and the performance of movements can be crucial in solving situational-motor problems that the graduates of the Faculty of Security Sciences may encounter in their lifetime commitment. The speed of motor reaction usually means the time of processing cer- tain information in which the corresponding movement begins. Mollon and Perkins (1996) think of reaction time as a time that is used as an indicator of the duration and complexity of mental processes. Similarly, Jensen (2006) interprets reaction time as a measure of the speed of the perceptual-cognitive system expressed through the time 
that elapses from the onset of the stimulus to the response. It is, in fact, a latent time in which certain regulatory processes take place, and which end with a corresponding terminal movement.

Given that security jobs do not exclude activities related to the use of physical force and that efficiency in solving situational-motor problems, especially in new situations, largely depends on the reaction time, it is very important that the graduates can make a decision as soon as possible, and implement an appropriate motor program. The speed of mental processing in real-time and the speed of performing rational and efficient movements is important not only in solving situational-motor problems but also in learning and improving the teaching material in Special Physical Education (Blagojević et al. 2019). Namely, with each type of learning, including motor learning, the task must first be understood, and the activity of the cerebral cortex is necessary for that. Moreover, in motor learning, we cannot exclude the muscular system either, because it takes place not only through the activity of the cortex but also through the feedback system, through the receptors located in the muscles. Depending on the complexity of the motor task the activity of the cortex changes. Thus, with simple tasks, the activity of the cortex is the lowest, and with somewhat more complex motor tasks, the activity is higher, while with complex motor tasks, where extremely large cognitive charges appear, the activity of the cerebral cortex is the highest (Bala, 1999). Therefore, unlike simple tasks, efficient and correct perceptual processing, i.e. cognitive functioning, has a very important say in solving complex motor problems that a professional security worker can encounter.

In the study conducted by Momirović and Horga (1982) which referred to the canonical relations of intellectual and motor abilities (rhythm, coordination, flexibility, strength, and endurance), it was concluded that general cognitive factor is mainly defined by the efficiency of the serial processor. It was also in a significant positive correlation, while with power and endurance it was negatively correlated. Bala (1999) obtained results through the battery of 23 motor tests and the KOG3 battery for the assessment of perceptual, serial and parallel processors, based on which it was concluded that a nonlinear data processing model showed significant correlation, and better explained the common variability of the analysed variable spaces. Additionally, the test of cognitive functioning is a better predictor of motor behaviour than vice versa.

Arlov et al. (1994 $)$ conducted a study on a sample of 45 karate masters to analyse the influence of different starting guards (diagonal and linear) on the time parameters of the technique of Gyako Tsuki (common use Japanese terminology) while the examinees were performing an attack, defence, and counterattack from different distances. Based on the analysis of quantitative differences, a diagonal guard could be proposed for fighters who choose a shortened or basic distance, while for fighters who fight from a long distance, the equal use of both guards was suggested. In addition, on the same sample of respondents, it was suggested to use both guards equally when conducting Mae Geri technique (Arlov et

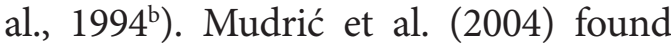
that the average values of the time of performing punches and kicks were different in relation to their complexity. It was stated that in more complex situations of attack, in relation to the situation of unconditional attack (when the respondents knew everything), the planning 
time increased and that the time partial parameters of planning an attack with hands were shorter than an attack with feet. He explained this by the fact that leg attacks were more complex techniques than hand-performed techniques. Guzvica et al. (2012) evaluated the speed of simple and complex motor reaction to a light signal with the fourth-year students of the College of Internal Affairs. The obtained results indicated that in a simple motor reaction men were statistically significantly faster than women, while women achieved a statistically significantly better result in a complex motor reaction at the initial speed of movement. However, when it comes to the dominant and weaker side for the whole sample, although there was a certain difference in the speed of the motor reaction, they did not get statistical significance. Vuković et al. (2019) measured the time of simple reaction and the time of choice reaction between preadolescent and early adolescent age boys and girls at different levels of karate training. They found that there was no statistically significant difference between boys and girls when it came to simple reaction time, but that they were statistically significant in terms of mastery. In addition, when it comes to the choice reaction time, statistically significant differences were obtained between the genders at the student level of training and at the subsample of boys.

The time that flows from the moment of occurrence to which one should react and realize a particular technique is a significant factor for the successful performance of police tasks. The educational process and permanent training should result in police officers' training to respond successfully in different situations. In this sense, the aim of this paper is to examine: 1) the time required to perform different modalities of techniques in a condition of one response to one stimulus under familiar conditions and in condition under an alternative stimulus introduced; 2) differences in realisation time between left and right techniques; 3 ) temporal differences between genders in the realisation of specific combat techniques; 4) the correlation between techniques temporal parameters and cognitive ability.

\section{RESEARCH METHODOLOGY}

This was transversal study, and the existing condition was determined by collecting data through specific tests of motor and spatial abilities. The measurement was performed using Witty SEM wireless training timer (model KD 520, CEI 68-4, Microgate, Bolzano, Italy, www.microgate.it). It was developed to test motor reaction time based on laser technique, and Witty Manager Software was used. Built-in proximity sensor, Witty SEM, allows reactivity testing for specific work on motor-cognitive and coordination skills with a measurement accuracy of $\pm 0.4 \mathrm{~ms}$.

\section{Sample of respondents}

The sample consisted of 44 third- ty Sciences in Banja Luka, of which 24 year students at the Faculty of Securi- were men and 20 were women, between 
21 and 22 years of age. In the previous schooling, which lasted two semesters, with a weekly load of six school hours, the students have mastered three levels of training in the subject of Special Physical Education. All subjects were clinically healthy, with no visible physical defects or morphological aberrations.

\section{Sample variables}

The sample of variables consisted of 15 motor tests and one test from a cybernetic battery of intelligence tests (KOG 3 ) - test $\mathrm{S} 1$. According to the results of the previous research (Paspalj, 2011), the spatial factor is statistically significantly positively related to solving problem situations from Special Physical Education, and is therefore separated from a cybernetic battery of intelligence tests (KOG 3 ) and used as one of the variables in this research. Test S1 was used to assess the quality of parallel light stimulus processing.

The motor variables related to the simple stimuli are as follows: punch forward from the spot (KZMJ), punch forward sliding
(KZUK), hop step and punch forward (KZDO), opposite hand punch from the spot (GZMJ), opposite hand punch sliding (GZUK), hop step and opposite hand punch (GZDO), opposite hand punch with step forward (GZIS), punch and step forward (OZ), kick from the spot (MGMJ), kick ding forward (MGUK), hop step and kick forward (MGDO), semicircular kick forward from the spot (MWGMJ), semicircular kick forward sliding (MWGUK), hop step and semicircular kick forward (MWGDO). The variable is moving forward and opposite hand punch (INGZ) was used to assess a response in conditions with an alternative stimulus introduced.

\section{Research procedure and method of measurement}

The research included measuring simple and complex motor responses to a light signal. The measurement was performed in the sports hall in the afternoon in February 2020 at a temperature of approximately $22^{\circ} \mathrm{C}$. The respondents were in the prescribed sports equipment and barefoot. The purpose of the research was explained to the students, after which they voluntarily started testing. Immediately before the test, the respondents were acquainted in detail with the tasks that were expected of them.

The time needed for technique realisation on simple stimulus was tested by the respondent, from a fighting stance and middle guard, having the task to react to a known light signal as quickly as possible, from a place, by moving forward ("slipping"), moving step forward and hop step, and taking a punch or a kick in the target. The time needed for technique realisation in conditions with an alternative stimulus introduced was assessed from the position of parallel feet (heiko dachi). With this time, the subject had a choice (50\% probability of one of the signals - L1 and L2). At the appearance of the L1 signal, the subject performed a step forward with the left foot and a punch with the right hand (GZ), and at the signal L2, they performed a step forward with the right foot and a punch with the left hand (GZ). They repeated tests three times, all three attempts were 
registered, and the best time was taken for statistical data processing. The pause between the previous and the next performance of motor tasks provided the necessary rest and maximum concentration of the subjects. Before performing the test, each respondent took the appropriate distance from the appropriate stance and guard, depending on the tasks. The light signal was located directly in front of the examinee, and the target was a signal lamp at the height of the examinee's head. The results were read at the end of the test, and the person who entered the results for control repeated the results aloud. They placed lamps (Figure 1) so that the subject could see them clearly - in front and at the width of the subject's shoulders so that the distance from the starting position of the subject and both lamps was equal. The time was measured from the beginning of the visual stimulus to the end of the punch or kick. The height of the lamps was adjusted according to the height of the subjects, and the stimulus was given sporadically, at different time intervals.

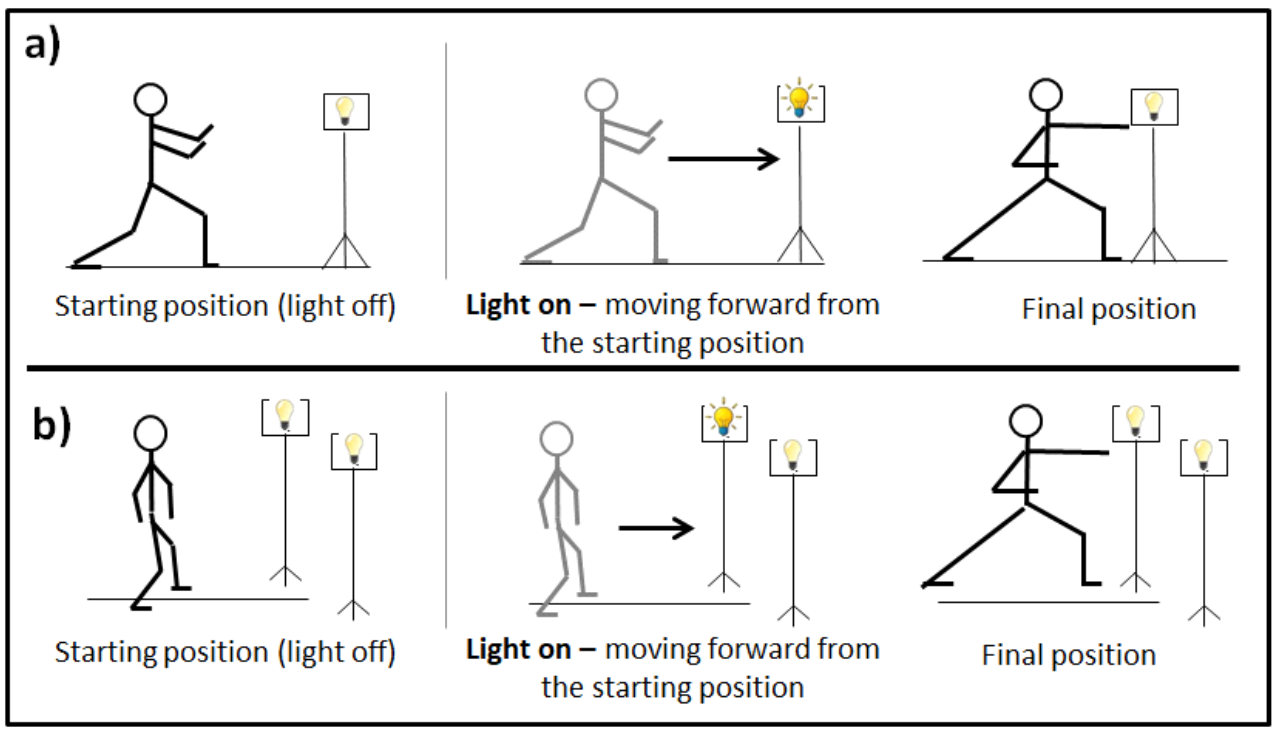

Figure 1. An example of testing technique in the condition a) of simple and b) alternative stimulus

The Intelligence Test Cybernetics Battery (KOG 3) contains three tests that evaluate the efficiency of the perceptual functions (IT-1 test) of the parallel processor functions (S-1) and the serial processor functions (AL-4). The S-1 test, adapted for population of respondents in this research, was used (Wolf et al., 1995). The test contained 30 tasks where each task had a three-dimensional representation of a group of bricks. The task of the respondents was to find, between the four transverse projections of that group, the one that corresponds to the given representation when that group is observed from a certain direction. The application time was eight minutes, so the test predominantly belongs to the category of strength tests. The metric characteristics (reliability, representativeness, and validity) of the test correspond to the highest psychometric standards (Wolf et al., 1992). Battery standardization was performed on a sample of 52,000 male respondents from Serbia, literate, and aged about 18-20 years (Wolf et al., 1995). 


\section{Statistical data processing}

The data obtained by the survey was processed by an appropriate statistical procedure. Basic descriptive indicators were calculated, the normality of data distribution was checked using the Kolmogorov-Smirnov test (K-S), and testing of the significance of differences in motor reaction rate between genders was performed by T-test of independent samples. The correlation between parallel information processing and motor reaction rate was calculated using correlation analysis. The analysis was conducted using the Statistical Package for Social Sciences (IBM, SPSS Statistics 20). The significance level was set at $95 \%$, i.e. $\mathrm{p} \leq 0.05$.

\section{RESULTS AND DISCUSSION}

Table 1 shows the central and dispersive parameters of the observed variables for men and women derived from the left guard.

Table 1. Descriptive indicators for man and women - left side

\begin{tabular}{ccccccccccc}
\hline Group & \multicolumn{7}{c}{ Men } & \multicolumn{7}{c}{ Women } \\
\hline Variable & Mean & Min & Max & SD & K-S & Mean & Min & Max & SD & K-S \\
\hline KZMJ & 0.43 & 0.39 & 0.48 & 0.02 & 0.32 & 0.43 & 0.39 & 0.48 & 0.03 & 0.16 \\
\hline KZUK & 0.59 & 0.47 & 0.72 & 0.07 & 0.57 & 0.58 & 0.53 & 0.71 & 0.06 & 0.04 \\
\hline KZDO & 0.80 & 0.74 & 0.86 & 0.05 & 0.02 & 0.84 & 0.80 & 0.93 & 0.04 & 0.01 \\
\hline GZMJ & 0.53 & 0.42 & 0.65 & 0.07 & 0.10 & 0.52 & 0.46 & 0.56 & 0.03 & 0.16 \\
\hline GZUK & 0.71 & 0.63 & 0.89 & 0.08 & 0.12 & 0.66 & 0.60 & 0.70 & 0.03 & 0.16 \\
\hline GZDO & 0.89 & 0.80 & 0.97 & 0.05 & 0.26 & 0.90 & 0.84 & 0.95 & 0.03 & 0.53 \\
\hline GZIS & 0.86 & 0.62 & 1.03 & 0.14 & 0.26 & 0.84 & 0.74 & 0.96 & 0.08 & 0.14 \\
\hline OZ & 0.87 & 0.82 & 0.96 & 0.06 & 0.01 & 0.80 & 0.76 & 0.86 & 0.04 & 0.16 \\
\hline MGMJ & 0.77 & 0.67 & 0.87 & 0.06 & 0.21 & 0.77 & 0.76 & 0.81 & 0.01 & 0.09 \\
\hline MGUK & 0.89 & 0.73 & 1.04 & 0.09 & 0.34 & 0.90 & 0.78 & 1.01 & 0.08 & 0.83 \\
\hline MGDO & 1.08 & 0.92 & 1.26 & 0.11 & 0.60 & 1.07 & 0.83 & 1.28 & 0.15 & 0.59 \\
\hline MWGMJ & 0.83 & 0.75 & 1.02 & 0.10 & 0.02 & 0.83 & 0.82 & 0.88 & 0.02 & 0.00 \\
\hline MWGUK & 0.97 & 0.86 & 1.08 & 0.09 & 0.03 & 0.95 & 0.79 & 1.09 & 0.10 & 0.39 \\
\hline MWGDO & 1.13 & 1.04 & 1.43 & 0.13 & 0.00 & 1.16 & 1.02 & 1.33 & 0.10 & 0.58 \\
\hline INGZ & 1.10 & 0.99 & 1.22 & 0.09 & 0.02 & 1.18 & 0.97 & 1.37 & 0.13 & 0.41 \\
\hline
\end{tabular}

Legend: Min - minimal result- in s, Max - maximal result- in s, Mean - mean value in s, SD standard deviation, K-S - Kolmogorov-Smirnov test value, KZMJ - punch forward from the spot, KZUK - punch forward sliding, KZDO - hop step and punch forward, GZMJ - opposite hand punch from the spot, GZUK - opposite hand punch sliding, GZDO - hop step and opposite hand punch, GZIS - opposite hand punch with step forward, OZ - punch and step forward, MGMJ - kick from the spot, MGUK - kick sliding forward, MGDO - hop step and kick forward, MWGMJ - semicircular kick forward from the spot, MWGUK - semicircular kick forward sliding, MWGDO - hop step and semicircular kick forward, INZG - moving forward and opposite hand punch 
By reviewing the results shown in the table, it can be determined that in most tests the results are homogeneous. The normality of the schedule was tested using the K-S test, and on that occasion deviations from the normal distribution of results were observed for certain variables. The largest range of results in men, and the largest deviation from the mean value was obtained with the variable GZIS. When it comes to women, the largest range of results, and the largest deviation from the mean value was recorded in the variable MGDO

Table 2 shows the central and dispersive parameters of the observed variables for men and women derived from the right guard. The largest range of results in male group, and the largest deviation from the mean value was recorded for the variable KZDO. The female group showed the largest range of results and the largest deviation from the mean value for the variable INGZ.

Table 2. Descriptive indicators for men and women - right side

\begin{tabular}{ccccccccccc}
\hline Group & \multicolumn{9}{c}{ Men } & \multicolumn{7}{c}{ Women } \\
\hline Variable & Mean & Min & Max & SD & K-S & Mean & Min & Max & SD & K-S \\
\hline KZMJ & 0.45 & 0.36 & 0.52 & 0.05 & 0.10 & 0.43 & 0.39 & 0.45 & 0.02 & 0.05 \\
\hline KZUK & 0.58 & 0.45 & 0.75 & 0.11 & 0.22 & 0.57 & 0.44 & 0.71 & 0.08 & 0.33 \\
\hline KZDO & 0.86 & 0.54 & 1.10 & 0.17 & 0.19 & 0.82 & 0.72 & 0.91 & 0.07 & 0.26 \\
\hline GZMJ & 0.53 & 0.47 & 0.64 & 0.06 & 0.07 & 0.46 & 0.44 & 0.48 & 0.01 & 0.05 \\
\hline GZUK & 0.69 & 0.62 & 0.79 & 0.06 & 0.03 & 0.61 & 0.57 & 0.66 & 0.03 & 0.11 \\
\hline GZDO & 0.95 & 0.87 & 1.11 & 0.07 & 0.24 & 0.85 & 0.72 & 0.97 & 0.08 & 0.52 \\
\hline GZIS & 0.98 & 0.83 & 1.09 & 0.09 & 0.09 & 0.88 & 0.70 & 0.98 & 0.11 & 0.01 \\
\hline OZ & 0.89 & 0.76 & 0.94 & 0.06 & 0.06 & 0.82 & 0.67 & 0.98 & 0.11 & 0.36 \\
\hline MGMJ & 0.76 & 0.65 & 0.90 & 0.07 & 0.10 & 0.78 & 0.73 & 0.85 & 0.04 & 0.25 \\
\hline MGUK & 0.96 & 0.74 & 1.15 & 0.13 & 0.10 & 0.98 & 0.88 & 1.03 & 0.05 & 0.05 \\
\hline MGDO & 1.25 & 1.03 & 1.44 & 0.14 & 0.17 & 1.14 & 0.99 & 1.30 & 0.12 & 0.24 \\
\hline MWGMJ & 0.92 & 0.75 & 1.05 & 0.10 & 0.06 & 0.86 & 0.75 & 0.99 & 0.10 & 0.17 \\
\hline MWGUK & 1.04 & 0.91 & 1.23 & 0.10 & 0.42 & 0.93 & 0.85 & 1.01 & 0.06 & 0.45 \\
\hline MWGDO & 1.28 & 0.98 & 1.49 & 0.16 & 0.12 & 1.16 & 1.07 & 1.34 & 0.09 & 0.02 \\
\hline INGZ & 1.08 & 0.99 & 1.35 & 0.12 & 0.00 & 1.22 & 0.87 & 1.45 & 0.20 & 0.33 \\
\hline
\end{tabular}

Legend: Min - minimal result in $s_{2}$ Max - maximal result in s, Mean - mean value, SD standard deviation, K-S - Kolmogorov-Smirnov test value, KZMJ - punch forward from the spot, KZUK - punch forward sliding, KZDO - hop step and punch forward, GZMJ opposite hand punch from the spot, GZUK - opposite hand punch sliding, GZDO - hop step and opposite hand punch, GZIS - opposite hand punch with step forward, OZ - punch and step forward, MGMJ - kick from the spot, MGUK - kick sliding forward, MGDO hop step and kick forward, MWGMJ - semicircular kick forward from the spot, MWGUK - semicircular kick forward sliding, MWGDO - hop step and semicircular kick forward, INZG - moving forward and opposite hand punch

This dispersion of the obtained results ences in psychomotor abilities (especialcan be attributed, primarily to different ly in coordination), i.e., different quality previous experiences and knowledge of adoption of the observed techniques. that the respondents had, their differ- When the obtained mean values of the 
results are observed, certain interesting things are noticed. Namely, the women in most cases (from both guards) achieved better results in most variables which relate to a motor reaction on simple stimuli, while the men achieved better results in a motor reaction when alternative stimulus is introduced.

Mudrić et al. (2004) examined the time parameters of karate attack techniques of the students at the College of Internal Affairs in Zemun. They obtained the integral time parameters of an unconditional attack: for a punch with a step (Oi Tsuki) - $936 \mathrm{~ms}$, for a punch with the opposite hand (Gyako Tsuki) - $961 \mathrm{~ms}$, for a kick forward (Mae Geri) - 865 ms and for a semi-circular kick (Mawashi Geri) - $986 \mathrm{~ms}$. The participants in this study, in comparison to the results in the above mentioned research, accomplished average values which were better $86 \mathrm{~ms}$ (9.19\%) for Oi Tsuki, $461 \mathrm{~ms}$ (47.97\%) for Gyako Tsuki, 95 ms (10.98\%) for Mae Geri, and $96 \mathrm{~ms}$ (9.74\%) for Mawashi Geri. A possible reason for those differences could be found in the instructions given to the participants. In this study, the instructions were to perform a technique as fast as possible, without emphasising the power.

Table 3 shows the differences between genders in the time of the techniques realisation from the left position. The results show statistically significant differences in four variables, two in favour of the men (KZDO and INGZ) and two in favour of the women (GZUK and OZ). Statistically significant differenc- es were not determined for variables KZDO, GZDO, MGUK, MWGDO, INGZ, KZUK, GZMJ, GZUK, GZIS, OZ, MGDO, and MWGUK. In the variables KZMJ, MGMJ and MWGMJ, men and women achieved identical results. When the obtained results are fully considered, although statistically significant differences were obtained in the same number of variables (two in favour of both genders), it could be noticed that women in most cases achieved better results compared to men. One of the possible explanations for the better results obtained from women in comparison to men lies in the fact that women are on average of lower heights and have shorter extremities, which is why they performed these techniques from a shorter distance. Accordingly, they performed techniques on a shorter path. In addition, a possible cause of such results may be previous experience and knowledge. The obtained a statistically significant difference in favour of men for the variable INGZ, when the alternative stimulus is introduced, could be explained by information processing speed. Additionally, men have better motor potentials for the realization of complex movements. If these results are compared with the study conducted by Guzvica et al. (2012), which was done on a similar population, it could be seen that similar results were obtained. However, in the mentioned research, it was noticed that women needed less time to process unknown information (they started the movement first), but men completed the terminal movement faster. 
Table 3. Differences between genders in the time of performing the technique from the left guard

\begin{tabular}{|c|c|c|c|c|c|c|c|c|c|}
\hline Variables & Group & Mean & SD & $\begin{array}{c}\text { Std. Error } \\
\text { Mean }\end{array}$ & $\mathbf{F}$ & df & $\begin{array}{c}\text { Sig. } \\
\text { (2-tailed) }\end{array}$ & $\begin{array}{l}\text { Mean Dif- } \\
\text { ference }\end{array}$ & $\begin{array}{l}\text { Std. Error } \\
\text { Difference }\end{array}$ \\
\hline \multirow{2}{*}{ KZMJ } & $\mathrm{M}$ & 0.43 & 0.02 & 0.00 & \multirow{2}{*}{1.38} & \multirow{2}{*}{42} & \multirow{2}{*}{0.82} & \multirow{2}{*}{-0.00} & \multirow{2}{*}{0.00} \\
\hline & $\mathrm{W}$ & 0.43 & 0.03 & 0.00 & & & & & \\
\hline \multirow{2}{*}{ KZUK } & M & 0.59 & 0.07 & 0.01 & \multirow{2}{*}{0.60} & \multirow{2}{*}{42} & \multirow{2}{*}{0.56} & \multirow{2}{*}{0.01} & \multirow{2}{*}{0.02} \\
\hline & $\mathrm{W}$ & 0.58 & 0.06 & 0.01 & & & & & \\
\hline \multirow{2}{*}{ KZDO } & M & 0.80 & 0.05 & 0.01 & \multirow{2}{*}{5.47} & \multirow{2}{*}{42} & \multirow{2}{*}{0.00} & \multirow{2}{*}{-0.04} & \multirow{2}{*}{0.01} \\
\hline & $\mathrm{W}$ & 0.84 & 0.04 & 0.01 & & & & & \\
\hline \multirow{2}{*}{ GZMJ } & M & 0.53 & 0.07 & 0.01 & \multirow{2}{*}{12.35} & \multirow{2}{*}{42} & \multirow{2}{*}{0.58} & \multirow{2}{*}{0.01} & \multirow{2}{*}{0.01} \\
\hline & $\mathrm{W}$ & 0.52 & 0.03 & 0.00 & & & & & \\
\hline \multirow{2}{*}{ GZUK } & M & 0.71 & 0.08 & 0.01 & \multirow{2}{*}{8.59} & \multirow{2}{*}{42} & \multirow{2}{*}{0.01} & \multirow{2}{*}{0.05} & 002 \\
\hline & $\mathrm{W}$ & 0.66 & 0.03 & 0.00 & & & & & 0.02 \\
\hline G7DO & M & 0.89 & 0.05 & 0.01 & 080 & 42 & 080 & - & 001 \\
\hline GLDU & $\mathrm{W}$ & 0.90 & 0.03 & 0.00 & 0.00 & 42 & 0.00 & -0.00 & 0.01 \\
\hline G7IS & M & 0.86 & 0.14 & 0.02 & 586 & 42 & 0.56 & 002 & 003 \\
\hline GLIS & $\mathrm{W}$ & 0.84 & 0.08 & 0.01 & 5.00 & 42 & 0.50 & 0.02 & 0.03 \\
\hline O7 & $\mathrm{M}$ & 0.87 & 0.06 & 0.01 & 801 & 42 & ( & 006 & 001 \\
\hline UZ & ŽW & 0.80 & 0.04 & 0.00 & 8.91 & 42 & 0.00 & 0.00 & 0.01 \\
\hline MGMI & $\mathrm{M}$ & 0.77 & 0.06 & 0.01 & 1142 & 42 & 008 & 000 & 001 \\
\hline IVIUIVI) & $\mathrm{W}$ & 0.77 & 0.01 & 0.00 & 11.42 & 42 & 0.90 & 0.00 & 0.01 \\
\hline MGUK & M & 0.89 & 0.09 & 0.01 & 013 & 42 & 079 & -000 & 002 \\
\hline IVIGUN & $\mathrm{W}$ & 0.90 & 0.08 & 0.01 & 0.13 & 42 & 0.19 & -0.00 & 0.02 \\
\hline MGDO & M & 1.08 & 0.11 & 0.02 & 104 & 42 & 070 & 001 & 003 \\
\hline IVIGD & $\mathrm{W}$ & 1.07 & 0.15 & 0.03 & 1.04 & 42 & 0.10 & 0.01 & 0.03 \\
\hline MWGMI & $\mathrm{M}$ & 0.83 & 0.10 & 0.02 & 33.09 & 42 & 0.98 & 0,00 & 0.02 \\
\hline ivivi uivis & W & 0.83 & 0.02 & 0.00 & 35.00 & 72 & 0.00 & 0.00 & 0.02 \\
\hline MWGUK & M & 0.97 & 0.09 & 0.01 & 0.88 & 42 & 0.60 & 0.01 & 0.02 \\
\hline DIVRUA & $\mathrm{W}$ & 0.95 & 0.10 & 0.02 & 0.88 & 42 & 0.00 & 0.01 & 0.02 \\
\hline MWG- & M & 1.13 & 0.13 & 0.02 & 051 & 42 & 039 & -003 & 003 \\
\hline DO & $\mathrm{W}$ & 1.16 & 0.10 & 0.02 & 0.01 & 42 & 0.59 & -0.05 & $0.0 \mathrm{~J}$ \\
\hline ING7 & M & 1.10 & 0.09 & 0.02 & 130 & 42 & 002 & -008 & 003 \\
\hline 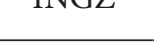 & $\mathrm{W}$ & 1.18 & 0.13 & 0.03 & 1.00 & 72 & 0.02 & -0.00 & 0.00 \\
\hline
\end{tabular}

Table 4 shows the differences between men and women in the time required for the realization of the examined motor tasks from the right posture. The analysis of the results shows that the women achieved better results in twelve variables: KZMJ, KZUK, KZDO, GZMJ, GZUK, GZDO, GZIS, OZ, MGDO, MWGMJ, MWGUK and MWGDO, while the men performed better on the following variables: MGMJ, MGUK and INGZ. However, a statistically significant difference was obtained in nine variables in favour of women, namely in the variables by which the simple motor reaction was assessed. These were: KZMJ, GZMJ, GZUK, GZDO, GZIS, OZ, MGDO, MWGUK and MWGDO in favour of women, while the statistically significant difference in men benefit was obtained for the variable INGZ. The previously given explanation relating to the derivation of left-handed strike techniques is entirely transferable to right-handed strike techniques. 
Gužvica, M. et al. (2020). Temporal differences between genders

in the realisation of specific combat techniques relative to spatial ability

Table 4. Differences between genders in the time of performing the technique from the right guard

\begin{tabular}{|c|c|c|c|c|c|c|c|c|c|}
\hline Variables & Group & Mean & $\begin{array}{c}\text { Std. } \\
\text { Deviation }\end{array}$ & $\begin{array}{c}\text { Std. Error } \\
\text { Mean }\end{array}$ & $\mathbf{F}$ & df & $\begin{array}{c}\text { Sig. } \\
\text { (2-tailed) }\end{array}$ & $\begin{array}{c}\text { Mean } \\
\text { Difference }\end{array}$ & $\begin{array}{l}\text { Std. Error } \\
\text { Difference }\end{array}$ \\
\hline \multirow{2}{*}{ KZMJ } & M & 0.45 & 0.57 & 0.01 & \multirow{2}{*}{21.13} & \multirow{2}{*}{42} & \multirow{2}{*}{0.04} & \multirow{2}{*}{0.02} & \multirow{2}{*}{0.01} \\
\hline & $\mathrm{W}$ & 0.43 & 0.22 & 0.00 & & & & & \\
\hline \multirow{2}{*}{ KZUK } & $\mathrm{M}$ & 0.58 & 0.11 & 0.02 & \multirow{2}{*}{1.94} & \multirow{2}{*}{42} & \multirow{2}{*}{0.74} & \multirow{2}{*}{0.01} & \multirow{2}{*}{0.03} \\
\hline & $\mathrm{W}$ & 0.57 & 0.08 & 0.01 & & & & & \\
\hline \multirow{2}{*}{ KZDO } & $\mathrm{M}$ & 0.86 & 0.17 & 0.03 & \multirow{2}{*}{6.55} & \multirow{2}{*}{42} & \multirow{2}{*}{0.34} & \multirow{2}{*}{0.04} & \multirow{2}{*}{0.04} \\
\hline & $\mathrm{W}$ & 0.82 & 0.07 & 0.01 & & & & & \\
\hline \multirow{2}{*}{ GZMJ } & $\mathrm{M}$ & 0.53 & 0.06 & 0.01 & \multirow{2}{*}{73.06} & \multirow{2}{*}{42} & \multirow{2}{*}{0.00} & \multirow{2}{*}{0.07} & \multirow{2}{*}{0.01} \\
\hline & $\mathrm{W}$ & 0.46 & 0.01 & 0.00 & & & & & \\
\hline \multirow{2}{*}{ GZUK } & $\mathrm{M}$ & 0.69 & 0.06 & 0.01 & \multirow{2}{*}{25.95} & \multirow{2}{*}{42} & \multirow{2}{*}{0.00} & \multirow{2}{*}{0.07} & 001 \\
\hline & $\mathrm{W}$ & 0.61 & 0.03 & 0.00 & & & & & 0.01 \\
\hline חמרד & $\mathrm{M}$ & 0.95 & 0.07 & 0.01 & 021 & 42 & 000 & 009 & בח0 \\
\hline ULD & $\mathrm{W}$ & 0.85 & 0.08 & 0.01 & 0.21 & 42 & 0.00 & 0.0 & 0.02 \\
\hline G7IS & $\mathrm{M}$ & 0.98 & 0.09 & 0.01 & 336 & 42 & 000 & 009 & 003 \\
\hline UET & $\mathrm{W}$ & 0.88 & 0.11 & 0.02 & 3.50 & 42 & 0.00 & 0.09 & 0.03 \\
\hline Q7 & $\mathrm{M}$ & 0.89 & 0.06 & 0.01 & 1281 & 42 & 001 & 007 & 002 \\
\hline UL & $\mathrm{W}$ & 0.82 & 0.11 & 0.02 & 12.01 & 42 & 0.01 & 0.07 & 0.02 \\
\hline MGMI & $\mathrm{M}$ & 0.76 & 0.07 & 0.01 & 491 & 42 & 033 & -001 & 001 \\
\hline ivenivit & W & 0.78 & 0.04 & 0.00 & 4.31 & 42 & 0.33 & -0.01 & 0.01 \\
\hline MGUK & $\mathrm{M}$ & 0.96 & 0.13 & 0.02 & 1253 & 42 & 060 & -001 & 003 \\
\hline NIUU & $\mathrm{W}$ & 0.98 & 0.05 & 0.01 & 12.03 & 42 & 0.00 & -0.01 & 0.00 \\
\hline MGDO & M & 1.25 & 0.14 & 0.02 & 060 & 42 & 001 & 0.10 & 004 \\
\hline IVIUI) & $\mathrm{W}$ & 1.14 & 0.12 & 0.02 & 0.00 & 42 & 0.01 & 0.10 & 0.04 \\
\hline MWGMI & M & 0.92 & 0.10 & 0.02 & 015 & 42 & 0.07 & 005 & 003 \\
\hline 1010 & W & 0.86 & 0.10 & 0.02 & 0.18 & $T 2$ & 0.07 & 0.0 & 0.00 \\
\hline MWGUK & M & 1.04 & 0.10 & 0.02 & 572 & 42 & 000 & 010 & 202 \\
\hline introur & W & 0.93 & 0.06 & 0.01 & 0.12 & 42 & 0.00 & 0.10 & 0.02 \\
\hline MWGDO & M & 1.28 & 0.16 & 0.03 & 679 & 42 & 000 & 0.12 & 0,04 \\
\hline ivivicus & W & 1.16 & 0.09 & 0.02 & 0.19 & 42 & 0.00 & 0.12 & 0.04 \\
\hline INGZ & $\mathrm{M}$ & 1.08 & 0.12 & 0.02 & 6.30 & 42 & 0.00 & -0.14 & 0,05 \\
\hline 11vUZ & $\mathrm{W}$ & 1.22 & 0.20 & 0.04 & 0.00 & 72 & 0.00 & 0.11 & 0.0 \\
\hline
\end{tabular}

Table 5 shows the results of the partial correlation of the S1 test with the variables of the manifest motor space from the left and right guard for both genders. For the techniques performed from the left position when it comes to men, the analysis showed the absence of any concurrence with the variables MGMJ, GZIS, MGDO, INGZ and MWGDO. Weak correlations was obtained with the variables MWGMJ, GZDO, KZDO, MGUK, OZ and KZMJ while significant correlations at the level of $\mathrm{p}<0.05$ were obtained with the variables KZUK and MWGUK. High correlations at the level of $p<0.01$ were obtained with the variables GZMJ and GZUK. The results of women showed the absence of any correlations of the variable $S 1$ with the variables MGMJ and MGDO, while poor correlations were recorded with the variables GZDO, OZ, GZMJ and KZDO. Significant correlations at the level of $\mathrm{p}<$ 0.05 were recorded with variables GZIS 
and GZUK and at the level of $\mathrm{p}<0.01$ with variables MWGUK and KZUK, while high and very high correlations at the level of $\mathrm{p}<0.01$ were recorded with variables MWDO, MGUK, KZMJ and INGZ. When it comes to right-handed techniques in the male group, the absence of any correlations with the variable S1 were noted for the variables OZ and MWMJ, while poor correlations were obtained with the variables INGZ and MGUK. Significant correlations at the level of $\mathrm{p}<0.05$ were obtained with the variables GZUK, KZMJ, and MGMJ, while significant correlations at the level of $p<0.01$ were obtained with the variables GZDO, GZMJ, MGDO, MWGDO and GZIS. High and very high correlations at the level of $p<0.01$ were obtained with the variables KZUK, KZDO and MWGUK. When it comes to women, for the techniques derived from the right guard, the absence of any correlations with the variable S1 was noted for the variables KZUK and GZMJ while the weak correlation was obtained with the variable MWGDO. Significant correlations at the level of $\mathrm{p}<0.05$ were obtained with the variables MWGMJ and GZIS, while significant correlations at the level of $\mathrm{p}<0.01$ were obtained with the variables GZUK, MGDO, MGMJ, KZMJ and KZDO. High and very high correlations at the level of $p<0.01$ were obtained with the variables MWGUK, OZ, INGZ, GZDO, and MGUK.

At first glance, the results obtained seem a bit confusing, especially when it comes to a complex motor reaction where the ability to educate is very important. If the observed variables, techniques are compared with natural movements, it is possible to claim that each performed technique has its own code, a record in the nervous system. However, almost all martial arts techniques are more or less modified, adapted, and shaped, in order to be as efficient as possible in their practical use. The observed techniques have also been modified and refined so that there is a certain deviation from coded, inherited movements. Some of them are coordinationally simpler, some more complex, but not to such an extent that they would represent a great cognitive effort. When the techniques are observed in relation to the time required to perform them, given their trajectory, it is easy to notice that they are performed at different path lengths. For example, techniques performed with the hands take less time than techniques performed with the legs (Mudrić et. al. 2004). If the techniques are observed from the point of view of their specification, it could be seen that their efficiency requires, above all, good genetic predisposition (explosive power, speed of individual movement, coordination, and balance), etc. With good performance of techniques, especially in cases of automatism, cognitive stress is minimal. Due to all the above, such results could have been expected. The least cognitive effort was required by the techniques with the least complexity of performance, namely: the punch with the opposite hand in place and the punch with the opposite hand by slipping, which is why a high agreement with the S1 test was obtained. Slightly higher cognitive stress was required for techniques that required greater mobility in the hip joints and techniques that required significant coordination of the whole body, while still being performed with movements that were not common to the subjects. Furthermore, the probability of signal occurrence in a complex motor reaction was $50 \%$, which is a high probability that the subjects were familiar with, so that the choice time was 
almost the same as in a simple motor reaction and did not require a significant cognitive charge.

Furthermore, due to the frequency of repetition of the same stimulus, it is possible that its uncertainty was lost, so the motor reaction time was shorter. In contrast, due to the expectation of increased difficulty of the task, certain insecurity in the performance of certain techniques, the activity time of the spa centres was extended, so a certain number of respondents needed more time to react to the light signal.
Thus, subjects with greater ability to process information in parallel, greater motor skills, especially those that frequently occur naturally, then better concentration, focus, and perception (which plays a very important role in cognitive functioning), were faster in motor response, especially if these are movements that are more complex and motions. In order to confirm these assumptions and clearly show the relationship between motor reaction and cognitive abilities, we need a more detailed longitudinal research.

Table 5. Correlation coefficients between the variable S1 and the variables for estimating the response to the light signal

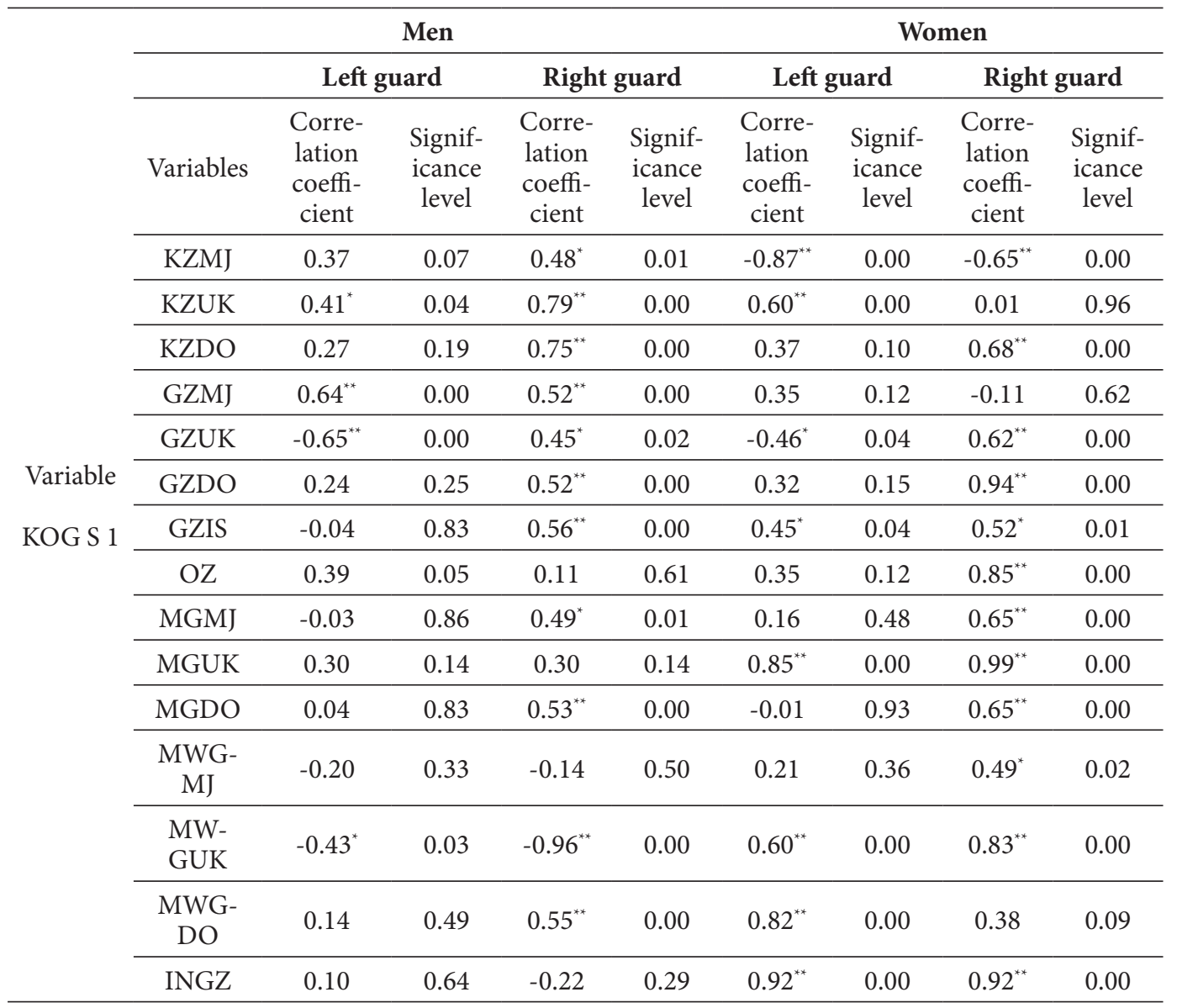

${ }^{*}$ The correlation is significant at the level of 0.01 (two-way); ${ }^{*}$ The correlation is significant at the level of 0.05 (two-way). 


\section{CONCLUSION}

Speed of motor reaction is an ability that is necessary for everyday life, and especially in solving situational-motor problems that the graduates from the Faculty of Security Sciences may encounter while performing their professional duties. The sample consisted of 44 respondents of both genders (24 men and 20 women) who were third-year students at the Faculty of Security Sciences. The study was conducted to determine temporal gender-related differences in performing particular modalities of kicks and punches, in the condition of one response to one stimulus and the situation under the alternative stimulus introduced. The results indicated that the women in most cases achieved better temporal results from the left position in comparison to the men when it comes to the technique realisation on a simple stimulus. On the other hand, the men achieved better results when the alternative stimulus is introduced. The explanation for these findings could be due to anthropometric characteristics, meaning that women are of lower height and consequently perform techniques on a shorter path. The better results that men achieved in the situation of complex stimulus are attributed to a higher level of genetically determined motor abilities, as well as to the faster processing of complex information. When it comes to motor response relationships with the $S 1$ test, which tested the ability to process in parallel, the results were explained by the amount of cognitive stress, higher motor skills, especially those characterized by high natural coefficients, but also better concentration, focus, and perception, especially in situations of more complex movements. The importance of the ability of motor reaction in performing safety tasks is taken into account, and the importance of this research can be seen in the possibility of selection, modelling, and further direction of students' training. It is expected that with carefully selected model characteristics of students and means of training and improvement, it is possible to achieve the practical applicability of martial arts techniques in real-life situations.

\section{REFERENCES}

Arlov, D., Milošević, M., Jovanović, S., Blagojević, M., Mudrić, R., \& Dopsaj, M. $\left(1994^{a}\right)$. Uticaj polaznog stava na vremenske parametre tehnike gjaku zuki. In Zbornik radova prvog savetovanja iz Specijalnog fizičkog obrazovanja (pp. 134-139). Beograd: Policijska akademija.

Arlov, D., Milošević, M., Jovanović, S., Blagojević, M., Mudrić, R., \& Dopsaj, M. $\left(1994^{\mathrm{b}}\right)$. Vremenski parametric tehnike Mae geri realizovane sa osnovne distance $\mathrm{u}$ funkciji polaznog stava. In Zbornik radova prvog savetovanja iz Specijalnog fizičkog obrazovanja (pp. 140-142). Beograd: Policijska akademija.

Arlov, D. (2002). Alati samoodbrane. Novi Sad: SIA.

Bala G. (1999). Struktura relacija motoričkih i kognitivnih dimenzija studenata fizičke kulture pod nelinearnim modelom. Psihologija, 32(3-4), 241-258. 
Blagojević, M., Koropanovski, N., Vučković, G., \& Dopsaj, M. (2019). Specijalno fizičko obrazovanje I: osnovni nivo. Beograd: Kriminalističko-policijski univerzitet.

Gužvica, M., Petrović, B., \& Vulin, L. (2012). Motoričke reakcije studenata Visoke škole unutrašnjih poslova na svjetlosni signal. In Antropološki aspekti sporta i fizičkog vaspitanja i rekreacije (pp. 132-140). Banjaluka: Fakultet fizičkog vaspitanja i sporta.

Jensen, A. (2006). Clocking the mind: Mental chronometry and individual differences. Amsterdam: Elsevier.

Mollon, J. D., \& Perkins, A. J. (1996). Errors of judgment at Greenwich in 1796. Nature, 380, 101-102.

Momirović, K., \& Horga, S. (1982). Kanoničke relacije hipotetskih dimenzija izvedenih iz mjera intelektualnih i motoričkih sposobnosti. Kineziologija, 14(5), 121-124.

Mudrić, R., Milošević, M., \& Jovanović, S. (2004). Napad u karateu: edukacija i trening. Beograd: Viša škola unutrašnjih poslova.

Paspalj, D. (2011). Morfološke karakteristike i psihomotoričke sposobnosti studenata Visoke škole unutrašnjih poslova u funkciji rješavanja problemskih situacija (Doctoral dissertation, Fakultet fizičkog vaspitanja i sporta Univerziteta u Banjoj Luci, Banja Luka, the Republic of Srpska).

Ratcliff, R., Van Zandt, T., \& McKoon, G. (1999). Connectionist and Diffusion Models of Reaction Time. Psychological Review, 106(2), 261-300.

Wolf, B., Momirović, K., \& Džamonja Z. (1992). KOG 3. Beograd: Savez društava psihologa Srbije, Centar za primenjenu psihologiju.

Wolf, B., Momirović, K., \& Džamonja Z. (1995). Baterija testova inteligencije KOG3. Kibernetička baterija konativnih testova KON 6. Psihologija, 28(3-4), 401-406.

Vuković, V., Marković, S., Koropanovski, N., Milovanović, M. \& Dopsaj, M. (2019). Differences between simple and choice reaction time among young karate athletes in relation to gender and level of training. Physical Culture Belgrade 73 (2), 238-249. (2), 238-249. 